\title{
Investment in intellectual capital and achievement of the competitive advantage in hotel sector
}

\author{
Qasim Mohammed Dahash ${ }^{\mathrm{a}}$ and Ammar Nazar Mustafa Al-Dirawi ${ }^{\mathrm{b}^{*}}$
}

${ }^{a}$ Assistant Lecturer, Finance and Banking Department, College of Administration and Economics, University of Basrah, Iraq ${ }^{b}$ Assistant Lecturer, Department of Business Administration, College of Administration and Economics, University of Basrah, Iraq

\section{CH R O N I L E ABS T RACT}

Article history:

Received: January 11, 2018

Received in revised format: March 3, 2018

Accepted: May 16, 2018

Available online:

May 16, 2018

Keywords:

Data Mining

Association rule mining

Inventory management

Cross-selling

ABC Classification

Clustering

\begin{abstract}
The primary objective of the research paper is to provide some insights on the concepts of intellectual capital and its important dimensions alongside to investigate the possible association between intellectual capital and attainment of competitive advantage. This study focuses on Iraqi hotel industry which is an under-research area in the context of intellectual capital and its relationship with competitive advantage. An adapted questionnaire was utilized to collect the responses from top and middle level managers of four and five-star hotels in Iraq. The reliability and validity of data collection instrument were measured through Cronbach's alpha, Composite Reliability and Average Variance Extracted respectively. The competitive advantage was then regressed against Human, Relational and Structural capital by application of Partial Least Square methodology. Results of the study showed a positive and strong connotation among intellectual capital and attainment of competitive advantage. The human capital had the highest contribution for competitive advantage in hotel sector of Iraq. The top management of hotels should take interest to develop, maintain and retain human capital to attain competitive advantage over competitors.
\end{abstract}

\section{Introduction}

The success and survival of originations in the current competitive environment and knowledge-based economy is largely dependable on creating, fortifying and preservation of competitive advantage. Mintzberg and Westley (1992) emphasis the fact that in order to accomplish and hold competitive advantage, originations need to offer superior quality products and services with greater value as compared with its competitors. In order to reach superior quality product and services, organizations have to maintain a superior information and knowledge along with the adaptation of best practices. Kong (2007), also proposed that knowledge owner (knowledge worker) through their intellectual capital are the sources of sustained competitive advantage. Some of unique features of intellectual capital proposed by Lin (2013, pp. 54-55) as a knowledge-based resource which is highly valuable are. "1) Intellectual capital is valuable, rare, imperfectly imitable and non-substitutable; 2 Intellectual capital is communicable to others; and 3) Components of intellectual capital are both distinctive and comprehensive"

\footnotetext{
* Corresponding author.

E-mail address: Maysoon.t.2016@gmail.com (A. N. M. Al-Dirawi)

(C) 2018 by the authors; licensee Growing Science, Canada doi: $10.5267 /$ j.msl.2018.5.007
} 
In the light of aforementioned unique characteristics, intellectual capital may be proposed as, one of the potential sources of achievement of competitive advantage for any organization. Kong and Prior (2008) highlighted that financial and physical assets are no longer the sources of attainment and sustainment of competitive advantage in the current global knowledge-based economy. In future, knowledge and application of knowledge can become of sources and foundation of competitive advantage due to emergence of globalization and Fourth Industrial Revolution. Porter (1998) described that Competitive advantage is a unique competitive position of any organization. In order to leverage competitive advantage, organizations require to differentiate themselves and make strategic moves ahead of the competing organizations to achieve the first mover advantage. Zimmer et al. (2005) proposed the role of human resource as the obtaining intellectual capital in imperative and essential. The competitive advantage is the combination of the factors that distinguishes any business from its competitors and provides a unique value proposition to consumer which is superior to the offerings of the competing players. If any organization wanted to achieve competitive advantage, the organization would have to either reduce the cost of production which could lead to low prices as compare to competitor or acquire some unique feature from the value chain that may result in offering differentiation in terms of products or services at a premium and justified price (Zimmerer et al., 2005).

Sofian et al. (2004) explained that intellectual capital is the professional knowledge, experience, skills, technological capacities and goad relationships, when they are coordinately applied towards the competitive advantage. Similarly, according to Schultz (1993), intellectual and human capital are one of the key assets of a company which helps to increase its productivity and supports in attaining competitive advantage.

The present study focuses on hotel industry of Iraq to dig out the role of intellectual capital for attaining competitive advantage. Traditionally Iraq is a tourism-based economy and the hotel industry has a central role in tourism development. The intense competition among hotels requires attaining competitive advantage to remain successful and profitable. Prior research has investigated the imperative pretended by intellectual capital in the Hospitality business. However, there are fewer studies which aimed at explaining the contribution of intellectual capital and its components in attaining competitive advantage (Bontis et al., 2002). The objective of the study is to explore the contribution of each component of intellectual capital for competitive advantage which ultimately improves the business performance. This will at that point enable us to distinguish the most basic components of intellectual capital for hotel industry. Further, we mean to investigate the significance of the intellectual capital for the hotel industry in Iraq to provide suggestions for executives and managers in hotel business with the goal that they can enhance their operations and pick up an advantage over competitors. This study is aimed to quantitatively explore and investigate the intellectual phenomenon in special circumstances of Iraqi hotel industry which is relatively unexplored industry. In this way this study will contribute to the existing knowledge by verifying the importance and the role of intellectual capital in a new geographical area which is neglected by researchers.

The rest of the research paper is structured in various sections, next section is designated to literature review of the multiple aspects of intellectual capital followed a section on detailed discussion on the link among intellectual capital and attainment of competitive advantage. Section three provides information on the methodology used for the current study. Fourth part of this paper is regarding the results and discussion followed by a section describing some of the limitations and final section concludes the paper.

\section{Literature review}

A thorough literature is reviewed on intellectual capital and its various dimensions like human capital, structural capital relational/customer capital. Various research studies have been conducted in order to establish framework that intellectual capital can be cradled and enhanced and superior organizational performance can lead to the achievement of the competitive advantage. 
Intellectual capital has been under discussed for more than a decade. Since then there has been no agreement on the definition of the term due to its emergence phase. There are various definitions proposed by the researchers, many researchers define intellectual capital in the special perspective of knowledgebased economy and the possible role of intellectual capital in the establishment of global knowledge based economy. Petty and Guthrie (2000) reported that the intellectual capital is gaining attentions both from practitioners and academic researchers. Khalique et al. (2013) proposed several dimensions of intellectual capital. Fig.1 shows numerous aspects of intellectual capital named as human capital/property, structural capital annd customer/relational capital.

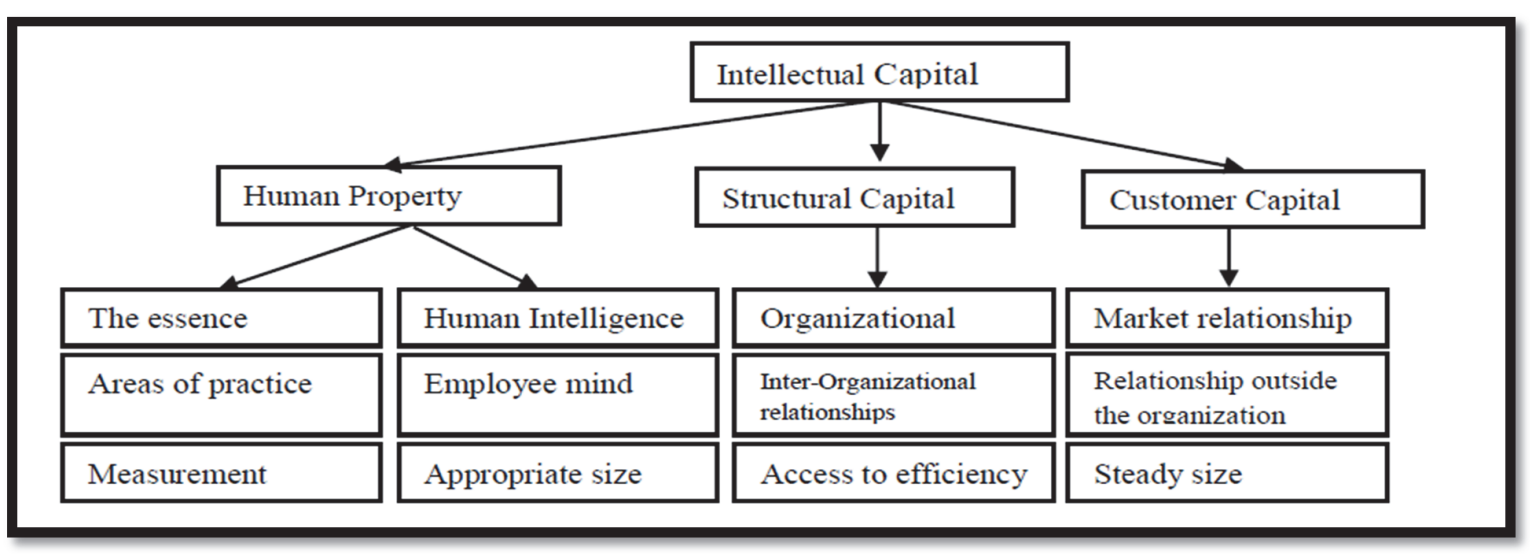

Fig. 1. The Multiple Dimensions of Intellectual Capital

Intellectual capital is therefore, includes the capabilities and resources that are uncommon valued, inimitable and not substitutable, which offer enduring competitive advantage and superior and enhanced performance (Barney, 1991). Intellectual capital is widely accepted to have three basic elements.

\subsection{Human Capital}

Human capital is very important element of intellectual capital (Sveiby, 1997). Human capital, is normally classified as the pivotal element and the driving force for the relational capital/customer capital and structural capital (Li and Chang, 2010). Furthermore, it includes the competencies and the capabilities of the employees which are vital to create value for company and customers. Specifically, they have tried equating the human capital with the combination skills, attitude, abilities and competencies of people which are contributing towards superior organizational productivity. The composition of the factors of production has changed the modern era where the knowledge has become one of the important factors of production (Sveiby, 1997). Therefore, superior quality of human capital ultimately produces high return by attaining competitive advantage (Bontis et al., 2002). Human capital can be described as how efficiently a company is using and exploiting the potential of human resources, learning skills, experience and education to obtain competitive advantage which leads to better profitability.

\subsection{Relational capital/customer capital}

Relational capital is also referred as customer capital which is related any organization with its external and internal stakeholders. The narrowed concepts of customer capital can be described as the relationship between the organization and its customer. Cabrita and Bontis (2008) articulated the relational capital as the knowledge and values embedded in the relationship with clients, corporate associations, suppliers, buyers or any other stakeholder that can influence the organization add value in the organization and can lead to better organizational performance. The organizations have to interact with the external stakeholders to exchange the knowledge and connect the external stakeholders with the organization (Kong \& Thomson, 2009). Relation knowledge is crucial in a sense to develop the perception of an organization for external stakeholders. It is important to communicate and constantly improve the knowledge on cus- 
tomers, government, society and distributors (Kong \& Thomson, 2009). As an important part of intellectual capital, relational capital helps to obtain better relationship with customers, mutual understanding with suppliers and the overall perception of the organization which is very important ingredients of a competitive advantage (Bontis, 2004). Conclusively, relational capital helps to maintain and develop interpersonal relation with external stakeholders (Gogan et al., 2016). Moreover, customer loyalty which has central position in current competitive arena is maintained and developed by strong relational capital (Shehzad et al., 2014).

\subsection{Structural capital}

The concept of structural capital is regarded as the systems and configuration of the organization that are in place for the employees for better productivity. These systems and structure remains intact event after employees leave the company (Edvinsson \& Malone, 1997). Structural capital can be seen as supportive and helps infrastructure which includes procedures, policies, and systems, which enable employees to perform up to their optimum potential and also help them enhance the capacity of any employee. The structural capital holds the ownership of the intellectual capital which is very important for an organization to develop human capital (Khanqah et al., 2012). In other words, structural capital is a way to add efficiency in human capital of an organization. The supportive environment is very important to exhaust human capital at its optimum level. Structural capital provides the supportive tools to human capital to endeavor new opportunities (Bontis, 1998). It is the systematic procedure and mechanism of an organization to run a business (Cuganesan, 2006). The specific culture of an organization is also the product of structural capital which helps human capital for manifestation while operating (Budiarti, 2017). It is the knowledge directory which is shared among the employees working in the organization and helps them exaggerate their capabilities at maximum level. The structural capital is the property of the organization and will remain with the organization when people leave. Therefore, it is the inimitable component of intellectual capital to create sustainable competitive advantage.

\subsection{Intellectual capital and competitive advantage}

The role and importance of intellectual capital, its impact on superior organizational performance which can lead to competitive advantage is discussed greatly in the existing research literature on the subject. Competitive advantage may only be achieved through the exploitation of resources which are scares, firm-specific assets and intangible in nature (Spender, 1996). Wang and Chang (2005) recognized intellectual capital as one of the fundamental determinants of organizational current and prospectus performance and competitiveness. Tovstiga and Tulugurova (2009) acknowledge that internal resources and most importantly its intellectual capital play a very pivotal role in the competitive outcome of small and medium size businesses. Additionally, they also noted that the attainment of competitive advantage was possible due to the mobility of the intellectual capital in the form of experience, knowledge, technical knowhow and strategic competencies. The existing research literature on the subject further confirms that the company's performance and competitive advantage is mainly influenced and determined by the application of intellectual capital (Barney, 1991; Tovstiga \& Tulugurova 2009). Competitive advantage is considered as an output of which is achieved through valuable, rare and human resources, supportive systems and customer relationship management, all these factors will lead towards sustainable competitive advantage. Bontis et al. (2002) described and connected human capital with competitive advantage and proposed that sustainable competitive advantage can only be achieved when employees are adding value in the organization, the value should be with unique characteristics and rare in nature.

\section{Research Framework}

Presently, there is an agreement among the researchers on the area, that intellectual capital can be classified in three broad dimensions, Human capital, structural capital and customer/ relational capital (Mouritsen et al., 2005; Cuganesan, 2006; Kim \& Kumar, 2009). Based on the existing literature the framework is proposed for the current study in Fig. 2 as follows. 


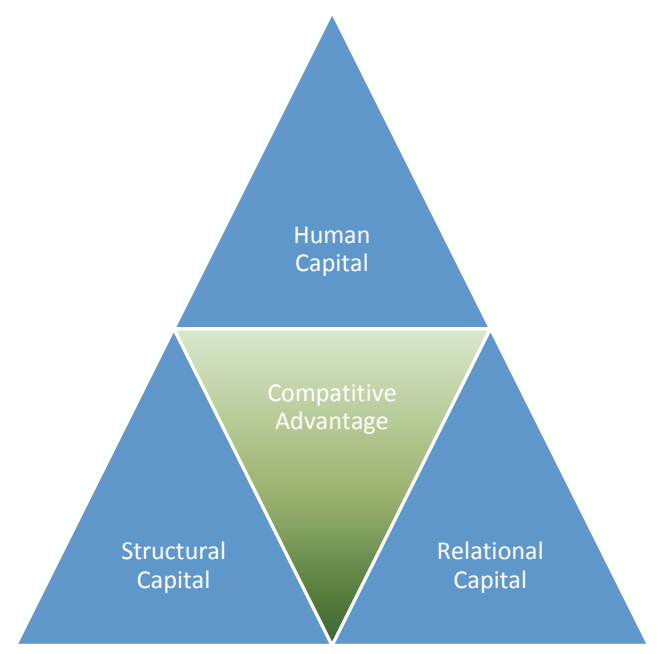

Fig. 2. Conceptual Model

As per the discussion and based on the previous research literature in the aforementioned deliberation and discussion the below mentioned hypothesws can be proposed for the present study.

Hsu and Fang (2009) proposed that high quality human resource is critical for the success and organizational performance.

Hypothesis $1-H 1$ Human capital is positively associated and linked with the performance of an organization, thus it's the source for competitive advantage in hotel sector of Iraq.

Subramaniam and Youndt (2005) described that competitive advantage could be achieved potentially through relational capital/customer capital, and the relational capital/customer should be embedded in the organizational network.

Hypothesis $2-\mathrm{H} 2$ Relational/customer capital is positively associated with competitive advantage of Iraqi hotels.

Kong and Prior (2008) proposed that structural capital is derived from the tacit knowledge of the employees of any company thus may be the possible source of achievement of competitive advantage.

Hypothesis $3-H 3$ Structural capital is strongly and positively associated with the competitive advantage of hotels in Iraq.

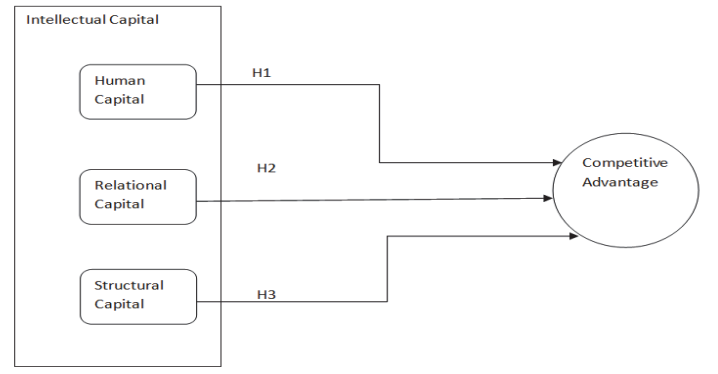

Fig. 3. Path Diagram

In this study, we select high class hotels to analyze the proposed model because the importance of intellectual capital in high cost hotel is more significant as compare with lower class hotels (Walsh et al., 2008). For this purpose, the hotels categorized into four stars and five stars were selected for this study. The data was collected through questionnaire and the questionnaire was adapted from past literature. Intellectual capital was subdivided into three dimensions; human capital, relational capital and structural 
capital. The three dimensions of intellectual capital were measured by utilizing Cabrita and Bontis (2008) scale. The instrument to measure intellectual capital consists of 61 items whereas, 20 items are developed to measure human capital, 25 items were utilize to measure relational capital and finally 16 items are used to measure structural capital. While the competitive advantage was measured by adapting the scale developed by Chahal and Bakshi (2015). The responses were collected on 5-point Likert scale. The unit of analysis for the study was upper scale hotels in Iraq (Basrah Hotel, Basrah International Hotel, Ishtar Sheraton Hotel Baghdad, Erbil International Hotel, Babylon Warwick Hotel Baghdad, Al Mansour Melea Hotel, Royal Tulip Al Rasheed Hotel Baghdad, and International Palestine Hotel Baghdad) and data were collected from top level and mid-level hotel managers through self-administrated questionnaire. A purposive sampling technique was adopted to select managers the randomly from selected hotels. In total, 118 managers were contacted for the purpose of data collection and finally 93 questionnaires were completely filled and selected for further analysis. The response rate is $78.8 \%$ which is adequate to generalize the results of this study (Sekaran \& Bougie, 2010).

\section{Data analysis and results}

The descriptive statistics is presented in Table 1. Mean, maximum and minimum values were calculated to give an overview of responses on variables. It is noted that human capital has the highest mean value among all the dimensions of intellectual capital. Moreover, Skewness and Kurtosis were calculated to examine the normality of data. All the variables are under the standardized values for skewness ( 3 to 3)and kurtosis (8 to _8) (Kline, 1998).

\section{Table 1}

Descriptive Statistics

\begin{tabular}{lccc}
\hline Variables & Mean & Skewness & Kurtosis \\
\hline Human Capital & 4.43 & -1.837 & -1.435 \\
Relational Capital & 4.01 & -1.947 & -0.947 \\
Structural Capital & 3.99 & -1.355 & -0.982 \\
Competitive Advantage & 4.65 & -1.483 & -0.752 \\
\hline
\end{tabular}

The reliability analysis was applied to measure the internal consistency of responses. Cronbach's alpha was calculating for each variables. The values of Cronbach's alpha are presented in Table 2, which revealed that the value of alpha for all the variables were in acceptable range (above 0.7) (Fornell \& Larcker, 1981; Nunnally, 1978).

Table 2

Reliability Analysis

\begin{tabular}{lll}
\hline Variables & Cronbach's Alpha & No. of Items \\
\hline Human Capital & 0.837 & 20 \\
Relational Capital & 0.873 & 25 \\
Structural Capital & 0.912 & 16 \\
Competitive Advantage & 0.823 & 12 \\
\hline
\end{tabular}

The validity analysis was carried out to measure the convergent and construct validity of instrument. The loading value of each variable and average variance extracted values were calculated and analyzed. The loading value for each variable is under 0.7 and the squared loading value is grater then 0.5 as presented in Table 3 (Vinzi et al., 2010; Nunnally, 1978).

Table 3

Convergent Validity Analysis

\begin{tabular}{lcc}
\hline Variables & Composite Reliability (CR) & Average Variance Extracted (AVE) \\
\hline Human Capital & 0.911 & 0.724 \\
Relational Capital & 0.831 & 0.889 \\
Structural Capital & 0.954 & 0.793 \\
Competitive Advantage & 0.843 & 0.810 \\
\hline
\end{tabular}


The construct validity of instrument has been analyzed by calculating the square root of average variance extracted. The value for square root of AVE was greater than the correlation among all variables in the scale (Table 4) which is accepted as mentioned by Chengalur-smith et al. (2012).

Table 4

Construct Validity

\begin{tabular}{lcccc}
\hline & Competitive Advantage & Human Capital & Relational Capital & Structural Capital \\
\hline Square Root AVE & $\mathbf{0 . 9 0}$ & $\mathbf{0 . 8 5 0}$ & $\mathbf{0 . 9 4 2 8}$ & $\mathbf{0 . 8 9 0}$ \\
AVE & 0.810 & 0.724 & 0.889 & 0.793 \\
\hline
\end{tabular}

The partial least square (PLS) method has also been applied to analyze the contribution of the intellectual capital for competitive advantage. Fig. 3 illustrates the path variables and corresponding coefficients. The statistics of structural model is presented in Table 5. The result shows the intellectual capital accounts for 0.538 or $53.8 \%$ variance in competitive advantage as represented by the value of $\mathrm{R}^{2}$. The beta coefficient of human capital has the highest contribution for competitive advantage (0.43). Similarly, relational capital has the second highest beta value in the model ( 0.31$)$. While structural capital has the lowest beta value in the model (0.24). The Table 5 illustrates that all the results are statistically significant.

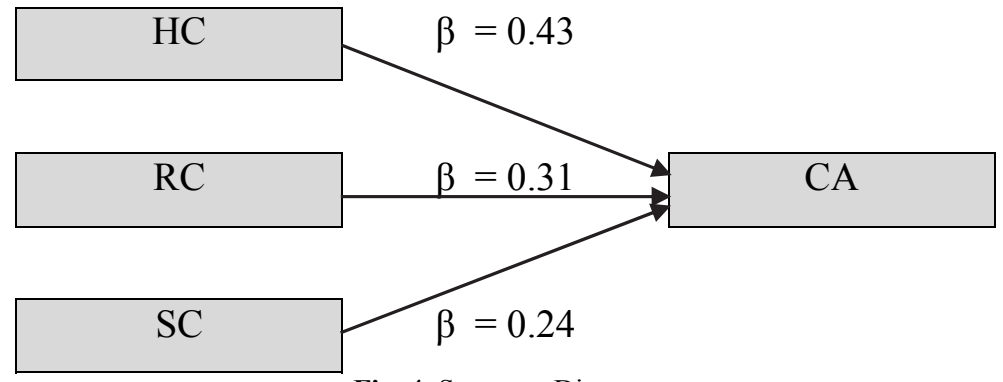

Table 5

Regression Results for Intellectual Capital

\begin{tabular}{llll}
\hline Path & & Coefficient & p-value \\
\hline Human Capital $\rightarrow \quad$ Competitive Advantage & 0.431 & 0.00 \\
Relational Capital $\rightarrow \quad$ Competitive Advantage & 0.317 & 0.034 \\
Structural Capital $\rightarrow \quad$ Competitive Advantage & 0.244 & 0.012 \\
\hline
\end{tabular}

\section{Discussion}

This study aimed to investigate the role of intellectual capital in attaining competitive advantage. Intellectual capital was measured through three dimensions as mentioned by Khalique et al. (2013). The results of this study evident that intellectual capital had a significant impact on competitive advantage in hotel sector of Iraq. The study revealed that firm's interest in human capital fundamentally influences its aggressive position in the market and industry. The findings of human capital impact on competitive advantage and they are consistent with the previous literature (Wang \& Chang, 2005; Hsu \& Fang, 2009). The paper suggests that the hotels should take interest in the activities to enhance to develop and enhance positive attitude in staff. Similarly, hotel management should invest in the training activities for employees to get competitive advantage in industry.

Furthermore, Relational capital has more clear effect on the company's upper hand than structural capital. Both relational capital and structural capital had positive relationship with competitive advantage. This study approves the findings of previous studies on relational capital and structural capital (Bontis, 1998; Wang \& Chang, 2005; Mehralian et al., 2013). It is noted that as explained by the results, all the dimensions of intellectual capital had a strong and significantly positive influence on attaining competitive advantage in Iraqi hotel industry. This study analyzed the individual contribution of three dimensions of 
intellectual capital for competitive advantage. The top management of hotels should understand the importance of human capital for competitive advantage. The relational and structural capital is also very important for achieving sustainable competitive advantage. The improvement in intellectual capital will help Iraqi hotels to get competitive advantage over the competitors and ultimately the business performance will improve.

\section{Conclusion and Recommendations}

The study aimed to analyze the role of intellectual capital components to attain competitive advantage in hotel industry of Iraq. The under study research phenomenon had lack of evidence in hotel industry; therefore, the reason for this investigation was to check the significance of intellectual capital in Iraqi setting. The examination has uncovered that intellectual capital had a fundamentally positive effect over competitive advantage. It was noticed that human capital strongly could influence on competitive advantage in hotel industry of Iraq, while structural capital had the lowest impact among three dimension of intellectual capital. Furthermore, the study was conducted in the Iraqi context which is a developing country. Therefore the results of this study need further verifications. It is expected that the different results could be revealed in different works and socio-economic settings. In addition, a longitudinal study is advised to record the dynamic impact of intellectual capital on competitive advantage over the period of time.

\section{References}

Barney, J. (1991). Firm resources and sustained competitive advantage. Journal of management, 17(1), 99-120.

Bontis, N. (1998). Intellectual capital: an exploratory study that develops measures and models. Management decision, 36(2), 63-76.

Bontis, N., Crossan, M. M., \& Hulland, J. (2002). Managing an organizational learning system by aligning stocks and flows. Journal of management studies, 39(4), 437-469.

Budiarti, I. (2017). Knowledge Management and Intellectual Capital-A Theoretical Perspective of Human Resource Strategies and Practices. European Journal of Economics and Business Studies, 8(1), 148-155.

Cabrita, M. D. R., \& Bontis, N. (2008). Intellectual capital and business performance in the Portuguese banking industry. International Journal of Technology Management, 43(1-3), 212-237.

Chahal, H., \& Bakshi, P. (2015). Examining intellectual capital and competitive advantage relationship. International Journal of Bank Marketing, 33(3), 376-399.

Chengalur-smith, I., Duchessi, P., \& Gil-garcia, J. R. (2012). Information \& management information sharing and business systems leveraging in supply chains : An empirical investigation of one webbased application. Information \& Management, 49(1), 58-67.

Fornell, C., \& Larcker, D. F. (1981). Structural Equation Models with Unobservable Variables and Measurement Error: Algebra and Statistics. Journal of Marketing Research, 18(3), 382.

Edvinsson, L., \& Malone, M. S. (1997). Intellectual capital: Realizing your company's true value by finding its hidden brainpower.

Gogan, L. M., Artene, A., Sarca, I., \& Draghici, A. (2016). The impact of intellectual capital on organizational performance. Procedia - Social and Behavioral Sciences, 221(0), 194-202.

Cuganesan, S. (2006). Reporting organisational performance in managing human resources: Intellectual capital or stakeholder perspectives?. Journal of Human Resource Costing \& Accounting, 10(3), 164188.

Hsu, Y.-H., \& Fang, W. (2009). Intellectual capital and new product development performance: The mediating role of organizational learning capability. Technological Forecasting and Social Change, 76(5), 664-677.

Kim, D. Y., \& Kumar, V. (2009). A framework for prioritization of intellectual capital indicators in R\&D. Journal of Intellectual Capital, 10(2), 277-293. 
Khalique, M., Shaari, N., Abdul, J., Isa, A. H. B. M., \& Samad, N. B. (2013). Impact of intellectual capital on the organizational performance of Islamic banking sector in Malaysia.

Khanqah, V. T., Khosroshahi, M. A., \& Ghanavati, E. (2012). An Empirical Investigation of the Impact of Intellectual Capital on Firms' Market Value and Financial Performance: Evidence from Iranian Companies. International Journal of Management Business Research, 2(1), 1-12.

Kline, R. B. (1998). Principles and practice of structural equation modeling. New York: Guilford Press.

Kong, E. (2007). The strategic importance of intellectual capital in the non-profit sector. Journal of Intellectual capital, 8(4), 721-731.

Kong, E., \& Prior, D. (2008). An intellectual capital perspective of competitive advantage in nonprofit organisations. International Journal of Nonprofit and Voluntary Sector Marketing, 13(2), 119-128.

Li, Q., \& Chang, C. (2010). The customer lifetime value in Taiwanese credit card market. African Journal of Business Management, 4(5), 702.

Lin, C. Y. Y. (2013). Intellectual Capital Explains a Country's Resilience to Financial Crisis: A Resource Based View. PO de Pablos, R. Tennyson, \& J. Yhao, Intellectual Capital Strategy Management for Knowledge-Based Organizations, 52-75.

Mehralian, G., Akhavan, P., Reza Rasekh, H., \& Rajabzadeh Ghatari, A. (2013). A framework for human capital indicators in knowledge- based industries: evidence from pharmaceutical industry. Measuring Business Excellence, 17(4), 88-101.

Mintzberg, H., \& Westley, F. (1992). Cycles of organizational change. Strategic management journal, 13(S2), 39-59.

Mouritsen, J., Thorsgaard Larsen, H., \& Bukh, P. N. (2005). Dealing with the knowledge economy: intellectual capital versus balanced scorecard. Journal of intellectual capital, 6(1), 8-27.

Nunnally, J. (1978). Psychometric Theory. New York: McGraw-Hill.

Petty, R., \& Guthrie, J. (2000). Intellectual capital literature review: measurement, reporting and management. Journal of intellectual capital, 1(2), 155-176.

Porter, M. E. (1998). Competing across locations: Enhancing competitive advantage through a global strategy. Harvard Business School Press.

Sekaran, U., \& Bougie, R. (2010). Uma Sekaran and Roger Bougie (fifth). Wiley and Sons, Ltd, Publication.

Shehzad, U., Fareed, Z., Zulfiqar, B., Shahzad, F., \& Latif, H. S. (2014). The impact of intellectual capital on the performance of universities. European Journal of Contemporary Education, 10(4), 273-280.

Vinzi, V. E., Chin, W. W., Henseler, J., \& Wang, H. (2010). Editorial: Perspectives on Partial Least Squares. In Handbook of Partial Least Squares (pp. 1-20).

Walsh, K., Enz, C. A., \& Canina, L. (2008). The impact of strategic orientation on intellectual capital investments in customer service firms. Journal of Service Research, 10(4), 300-317.

Wang, W.-Y., \& Chang, C. (2005). Intellectual capital and performance in causal models: Evidence from the information technology industry in Taiwan. Journal of Intellectual Capital, 6(2), 222-236.

Schultz, T. W. (1993). The economic importance of human capital in modernization. Education economics, 1(1), 13-19.

Sofian, S., Tayles, M., \& Pike, R. H. (2004). Intellectual capital: an evolutionary change in management accounting practices. University of Bradford, School of Management.

Spender, J. C. (1996). Making knowledge the basis of a dynamic theory of the firm. Strategic Management Journal, 17(S2), 45-62.

Subramaniam, M., \& Youndt, M. A. (2005). The influence of intellectual capital on the types of innovative capabilities. Academy of Management journal, 48(3), 450-463.

Tovstiga, G., \& Tulugurova, E. (2009). Intellectual capital practices: a four-region comparative study. Journal of Intellectual Capital, 10(1), 70-80.

Sveiby, K. E. (1997). The new organizational wealth: Managing \& measuring knowledge-based assets. Berrett-Koehler Publishers.

Zimmerer, T. W., Scarborough, N. M., \& Wilson, D. (2005). Essentials of entrepreneurship and small business management. Upper Saddle River, NJ: Pearson/Prentice Hall. 
(C) 2018 by the authors; licensee Growing Science, Canada. This is an open access article distributed under the terms and conditions of the Creative Commons Attribution (CCBY) license (http://creativecommons.org/licenses/by/4.0/). 